\title{
Factors Limiting the Full-scale Adoption of Process and Product Innovation in the Nigerian Construction Industry
}

Emmanuel Chidiebere Eze ${ }^{1}$

Onyinye Sofolahan

Adesoji Anthony Adegboyega

Kenneth John Saidu
Quantity Surveying Department, Federal University of Technology, Minna, Nigeria.

Quantity Surveying Department, Lagos State Polytechnic, Lagos state, Nigeria

Quantity Surveying Department, Waziri Umaru Federal Polytechnic Birnin Kebbi, Nigeria

Quantity Surveying Department, Federal University of Technology, Minna, Nigeria
Article History

Received 2019-04-15

Revised 2019-05-07

Accepted 2019-05-09

Published 2019-05-14

Keywords

Construction Industry

Barriers

Innovation

Contractors

Consultants

How to cite?

Eze, E. C., Sofolahan, O., Adegboyega, A. A., \& Saidu, K. J. (2019). Factors

Limiting the Full-scale Adoption of

Process and Product Innovation in the

Nigerian Construction Industry.

SEISENSE Journal of Management,

2(3), 67-81.

doi:10.33215/sjom.v2i3.145

Copyright (C) 2019 The Author(s)

(cc) BY
Abstract

Purpose- The aim of this study is to assess the factors limiting the full-scale adoption of process and product innovation by construction organizations in Nigeria with a view to suggesting probable ways of eliminating them

Design/Methodology- The study adopted a questionnaire survey approach in which data were collected from the participants using simple random sampling techniques in the study area. Frequency, percentage, mean item score, and Independent sample T-test was used to analyze the gathered data.

Findings- It was found that poor funding, poor support and commitment from management, fragmented nature of the construction business, poor coordination and communication among project participants, lack of qualified and experienced staff and the unwillingness of clients to pay for innovative ideas are the factors limiting innovations in construction.

Practical Implications- The outcome of this study will give the management of construction-based organizations an insight into the major limiting factors of innovation, so that appropriate strategies for overcoming them could be developed at the conception stage of construction projects.

\footnotetext{
${ }^{1}$ Corresponding author's email address: emmanueleze001@gmail.com
} 


\section{Introduction}

The construction industry is an influencer and accelerator of economic growth and development of nations. The effects of the industry are felt mostly in areas of job creation, its contributions to the national gross domestic product, improved firms revenue generation and competitive advantages, infrastructural developments and housing provisions. Thus, a vibrant and booming construction industry is healthy for the national and economic growth of every country (Eriksson, 2013; Hunt \& Gonzalez, 2018). The high level of growth experienced in the economy of US stems from their firms' ability to develop and adopt innovative processes in their dealings. This involve the use of new products and services, introduction and adaptation of technologies, and efficient implementation of modern techniques and methodologies (Benmansour \& Hogg, 2002).

In spite of the enormous benefits of the construction industry, it is faced with low productivity, poor quality, time and cost overruns. According to Alinaitwe, Widen, Mwakali, and Hansson (2006), in comparison with other industries, the construction industry experiences low productivity, quality and product functionality issues. Gann (2001) attributes the problems of construction to weak innovation. Similarly, construction industry over a long period of time has remained behind in the adoption of new technologies (Brandon, Kocatürk, \& Foundation, 2008; Peansupap \& Peansupap, 2004; Wong, 2007). Thus, the construction sector is said to be technologically backward with regards to innovation when compared to other sectors of the economy (Winch, 2003). In the same vein, construction is adjudged traditional industry with a dissatisfactory performance compared with the IT or manufacturing industry; the development of construction is yet to be advanced (Wei \& Lam, 2014).

Innovation in the Nigerian is still hovering around the late adopters and early adopters of innovation. Moohammad, Nor'Aini, and Kamal (2014) found that construction consultants in Nigeria fell within Adopters' category. This shows that a lot needs to be done to get to the initiator category. For the full potentials of innovations to be exploited by construction organizations in Nigeria, they need to embrace innovation in all their dealings. Thus, an innovation which is the application of new knowledge to construction activities including new products and process, organizational change, social changes, is desired. Since changes are a constant phenomenon, there is a need to effectively respond to the ever-increasing population from births and immigration, through innovative building production techniques (Alinaitwe et al., 2006).

Innovation repositions and strengthens the competitive advantage and revenue drive of corporate businesses. Construction organizations which innovate regularly are adjudged experts in the management of changes (Kelley, 2010). Demir and Kocabaş (2010) assert that progressive construction innovation is regarded as a competitive growth enhancer. It is argued that organizations that are more likely to survive the turbulent construction business environment will be those that add value to clients' through innovative ideas and excellent performance (Preece, Haron, \& Abdullah, 2008).

In Uganda, Alinaitwe et al. (2006) reviewed the barriers and enablers of innovation that affect productivity in the building industry and reported that the size of the domestic market and the level of security are the major innovation barriers that lead to low productivity. Wei and Lam (2014) examined innovation barriers at the project level in the UK construction industry, with the aim of identifying major barriers to innovation. The study found that client industry relationship, organization management, procurement, organizational culture, are the major barriers to innovation as perceived at the project level. Yankah and Dadzie (2015) examined the drivers, enablers and barriers to the performance of innovation in Quantity Surveying Firms, and found that these factors affect the performance of innovation in Quantity surveying firms. Benmansour and Hogg (2002) investigated the relevance of innovation barriers within the construction sector of the UK and concluded that there a generic factor that hinders the adoption of innovation. 
Alaghbandrad, Asnaashari, and Preece (2012) evaluated the Problems and barriers of ICT utilization on Iranian construction sites. The study found that poor ICT infrastructure, lack of local personnel familiar with ICT systems in remote construction sites, no economic justification for ICT training of personnel in small construction sites among others are the major barriers to ICT utilization. Usman (2014) reviewed the key factors that affect the adoption of technology in the Nigerian construction firms and found that culture, policy, and cost are key to the adoption of technology. Sargent, Hyland, and Sawang (2012) investigated the factors influencing the adoption of information technology in the construction business and found that the intention of an individual to use information technology is influenced by top management support, internal facilitating conditions and effort expectancy. Also, the fear/ resistance to new ways (changes) influence the adoption of innovation.

It is obvious from these studies that a study on the factors that are limiting the process and product innovation among construction organizations especially in the study area is still lacking. It is based on this knowing that this study is founded. Therefore, the aim of this study is to evaluate the factors limiting the fullscale adoption of process and product innovation by construction organizations (contractors and consultants) in Nigeria with a view to suggesting probable ways to eliminating them. The hypothesis that guided this study is; there is no statistically significant difference between the views of the contractors and consultants regarding the limiting factors of innovation.

The outcome of this study will give management insight into the major issues hindering the adopting of innovation so that strategies for overcoming them could be put in place at the conception stage of construction projects. It will also add to the body of knowledge available on innovation in construction.

\section{Literature Review}

\section{Attributes of Innovation in Construction}

The unique and numerous features of construction work affect the practice of innovation. The construction industry is fragmented and made up of many different trades, professions, and organizations. It is completely project-based with complex tasks (Bresnen, Goussevskaia, \& Swan, 2005; Hunt \& Gonzalez, 2018). Construction projects are time bound, the value chains are long and complex, there are many substantial regulatory influences, and the industry is conservative (Dewick \& Miozzo, 2002; Pöyhönen, Kajander, \& Sivunen, 2016). Regulations drive hinder construction innovation (Pöyhönen et al., 2016). The characteristic of construction poses challenges to innovation. Innovations in construction are incremental instead of being targeted at gaining new market. Construction firms are usually faced with issues such as team building and development, high intensity of Research and Development, and commercialization management (Pöyhönen et al., 2016; Sivunen, Pulkka, Heinonen, Kajander, \& Junnila, 2013). Innovation is cost-intensive with an indefinite return and most construction businesses lack the requisite and appropriate tools to manage the processes (Lim, Schultmann, \& Ofori, 2010; Manley, 2008; Pöyhönen et al., 2016). It was found that innovative processes that involve clients (customers) and value network are not broadly adapted among construction firms (Pöyhönen et al., 2016). Pöyhönen et al. (2016) confirmed that at the company level, there is an insufficient system for managing innovation problems by construction companies.

Other issues such as quality expectation, durability, nature of the construction project, project performance characteristics and expectations do not give room for innovation to thrive. Construction contracts and the procurement system are still being done traditionally Eriksson (2013), and this does not give room for innovation. The separation of design and construction in modern procurement systems, like the design and build contracts to reduces collaboration, relationships and discourages innovation (Kumaraswamy \& Dulaimi, 
2001). According to Eriksson (2013), since this procurement system is still based on the lowest price techniques, there is little or no incentive for the contractor to make a claim for additional innovative design.

A significant level of risks is added to the organization implementing innovation. The effect of new and unfamiliar knowledge introduction in the project environment can have secondary and tertiary effects, which would be difficult to foresee (Slaughter, 2000). For new knowledge to be successfully implemented, it must get the buy-in of all stakeholders within the organization (Blayse \& Manley, 2004).

These complexities impede the exchange of innovative practices within the firms and between organizations; thus, influencing the ability of the organization to learn from experience and create new techniques (Gann, 2001; Hunt \& Gonzalez, 2018). Davidson (2013) posits that the successful delivery of a project is anchored on the experiences and competencies of the employees. Construction companies at the local level constantly innovate and develop creative solutions to solve the varieties of specific problems encountered during construction; such innovations, however, saves cost and time, but are usually not developed into a marketable proportion. As such, innovation suffers and remained un-marketed, unpublicized due to lack of fund for research and development (Aouad, Ozorhon, \& Abbott, 2010).

\section{Benefits of Innovation}

According to Slaughter (1998), innovation is the genuine and conscious application of substantial improvement and change in the overall system that is exceptional to the organization developing and inventing the change. The implementation of creative ideas within an organization is regarded as an innovation. Goh (2005) asserts that in most developing economies, innovation is the fundamental factor that determines the growth of organizations and it is pivotal to their competitiveness within the industry. Thus, according to Barrett and Sexton (2006), the sustenance of competitive advantage stems from a balance and logical integration of innovation in firms' policy documents. Dulaimi, Nepal, and Park (2005) and Shaw (2010) argued that the devastating cost-based competition of the construction industry could be cushioned through innovation.

Similarly, it is through the formation of new value propositions, the offering of distinctive products/services, and increasingly redefining the cost performance margin, that firms strengthen their competitive advantages (Dodgson, Gann, \& Salter, 2005; Shaw, 2010). This can only be achieved through innovation. Reichstein, Salter, and Gann (2005) and Goh (2005) posit that during periods of recession, the revenue generation and profits of innovative firms are increased and sustained. Thus, innovation increases market penetration and widens profit maximization as it is a strategic competitive tool when properly used (Goh, 2005; Seaden, Guolla, Doutriaux, \& Nash, 2003). It leads to repeat patronage and a sustained relationship with clients. Seaden et al. (2003) and Dulaimi et al. (2005) who posited that the chances of securing new jobs and satisfying client desires could be improved upon through innovation supported this.

Innovation drives every organization and allows companies to differentiate themselves from their competitors, and at the same time providing value to customers and partners, gaining new markets and even creating completely new ones (Mazzola, Oliveira Junior, Esteves, \& Barreto, 2018). It is not only the companies that benefit from innovation but also society at large. Innovation contributes to employment, quality of life, productivity, and competitiveness. Since competition is what cannot be stopped or control internally, there is, therefore, the need for a consistent effort by organizations to renew themselves in order to remain competitive (Mazzola et al., 2018).

\section{Limiting Factors of Process and Product Innovation}

A lot of factors limit innovation in corporate businesses, and construction organizations are not an exception. Many firms are reluctant and opposed to the aggressive dynamics in innovation and technology, and as such 
are not willing to invest in innovation (Kuczmarski, 1996). These attitudes have been attributed to the difficulty in shifting to new techniques, discarding of existing decision-making pattern, strategic changes and realignment, learning from history and experience (Benmansour \& Hogg, 2002). Thus, the efforts of most firms are more of experimentation and no objective of incorporating innovation into its structures and operations (Dougherty, 2006).

There is the existence of hindrances to the uptake of innovation in the construction industry of especially developing countries of the world. For example, in Ghana, Yankah and Dadzie (2015) reported that the innovative activities of quantity surveyors are mostly hindered by the availability of financial resources, economic conditions, fragmented nature of construction business, inappropriate legislation, believe that the industry is doing well without innovation, and lack of qualified staff. The barriers to innovation according to Wei and Lam (2014) are; the need for support and consensus from owners and designers, limited budgets, uninformed and experienced clients, one-off nature of construction projects, clients low desire to pay for innovative solutions, poor management of knowledge transfer, short-term budgets and planning horizons, lack of motivators for innovation, lack of commitment and support from project managers, high level of subcontracting, project time scale, procurement systems which place a premium on speed, urgency or prices, and stringent regulations.

According to Egan (1998), the fragmented nature of the construction industry impedes improvement in performance. The reluctance to embrace new techniques and ideas, clients' lack of access to new techniques and/or innovative ideas are also limiting factors of innovation (Morledge, 2000). Also, the construction industry is project-based in nature as pointed out by Winch (1998) and reluctance to embrace the potentials of value management by contractors/consultants Benmansour and Hogg (2002), significantly limit innovation. Egbu et al. (1998) observed that the two major barriers to innovation are cognitive and emotional barriers; and identified the cognitive components to include lack or insufficient coherent information, lack or insufficient support from senior management and/or colleagues, lack or insufficient resources, and lack of positive motivational constructs. The emotional components include an unwillingness to take a risk, entrenched cultural norms, real or perceived threats to power and influence, the anxiety of losing job and fear of failure.

The management of most industries is usually unwilling to adopt new ways of doing things, especially when they are not convinced of the benefits. Fairclough (2002) submits that construction has been globally criticized for its sluggish and unhurried disposition to acceptance of novel organizational practices, procedures and new techniques. The top management responsibilities are to encourage employees and make them break their opposition to innovative alterations. To win the war of unwillingness to accept changes in construction organizations, top management has to be initiators and lovers of innovation.

Poor educational and training system, neglects of talents among the society, inadequate/lack of infrastructure, unsuitable legislation, intolerance of fanatics, top management isolation, short-term horizons, excessive rationalism, poor incentives, accounting practices and bureaucracy (OECD, 1992; Quinn, 1985). Storey (2000) stressed that financial system and regulation are barriers to innovation at macro-level; and organizational culture coupled with its structure, team dynamics, personal traits, resources and communication are the barriers to innovation at micro-level.

The size of the domestic construction market, level of security and government interference and management was identified by Alinaitwe et al. (2006) as the most ranked barriers to innovation in the construction industry. It was pointed out that Lack of technology, lack of experienced and qualified staff, time constraint, financial constraint, and government policy are barriers to innovations(Benmansour \& Hogg, 2002). 


\section{Research Methodology}

The study sought to assess the perception of construction and consulting organizations regarding the factors limiting the full-scale adoption of process and product innovation in Nigeria, using Abuja the country's capital as the study area. Abuja was chosen for this study as it is the administrative headquarters of Nigeria, and houses a lot of construction and consulting firms and professionals, who are regularly involved and engaged with construction activities.

The study adopted a questionnaire survey approach for soliciting quantitative data from construction based professionals working with construction/consulting firms and organizations. The use of a questionnaire is common in social research, and for collecting sample-based data (Blaxter, Hughes, \& Tight, 2001; Tan, 2008). According to Aghimien, Oke, and Aigbavboa (2018), the questionnaire is easy to use and have the ability to cover a wider range of participants.

The professionals sampled include Engineers (civil/structural \& services), Architects, Quantity Surveyors and Builders. They were chosen based on their organizations' involvement and active participation in construction activities. The study targeted organizations and companies rendering construction and developmental services, and who have implemented innovative techniques in their operations. These construction-based organizations include those who are involved in either general or specialized construction works or both, and they are engineering companies, estate management firms, architecture firms, quantity surveying firms, and general construction contractors.

A total of 342 questionnaires were administered to the respondents and 176 of them were retrieved, 4 discarded as a result of incomplete responses. Only 172 were deemed fit and used for the analysis. This represents a valid response rate of $50.29 \%$, which is well above the $20-30 \%$ response rate ideal for unbiased construction based study (Akintoye, 2000; Moser \& Kalton, 2001). This consists of 100 returns from contractors and 72 from consulting organizations. Data collection was achieved through self-administration of the questionnaire by the researchers and trained field assistant who were adequately briefed about the study objectives.

The questionnaire used was designed in two sections using information derived from the review of the related literature. Section A covered the general information of the target respondents. Information gathered from section A served as a quality check and verification of the data from the other part of the questionnaire. Section B covered the factors limiting the full-scale adoption of innovation in construction-based organizations. The respondents were required to rate the degree to which the identified factors have hindered the uptake and expansion of innovative activities in their organizations. This was based on a 5-point Likert scale, where $1=$ not influential, $2=$ less influential, $3=$ averagely influential, $4=$ influential, and $5=$ very influential.

To test the suitability and appropriateness of the questionnaire to meet the study objectives as suggested by (Fellows and Liu, 2008), a pilot study was adopted. Six (6) of the initial draft of the questionnaire were randomly distributed to the selected professionals in contracting and consulting firms and based on their feedback, the final draft was made.

Furthermore, the reliability and internal consistency of the questionnaire was carried out using Cronbach's alpha test. This test measured the reliability of each of the field of the questionnaire and the mean of the entire fields of the same questionnaire. The acceptable value range of Cronbach alpha is between 0.0 and +1.0 and as the value tends toward 1, the higher the degree of internal consistency. The Cronbach alpha value for the variables is 0.836 , thereby implying that the questionnaire is credible and have a high degree of reliability. 
According to Moser and Kalton (2001), a research instrument is perfect as the value of the Cronbach alpha tends towards 1.0.

For the first section, the data collected on the general information of the respondents were analyzed using frequency and percentage. For the second section of the questionnaire, mean item score was used in the ranking of the data collected on the factors identified, and independent sample T-test was used in determining the relationship in the views of the two respondents' organizations group, and for testing the hypothesis. Descriptive statistics (e.g. frequency, percentage, mean item score) were used for two (2) reasons, firstly, is to describe the respondents general information. Secondly was to check the respondents view for possible violation/direction for interpreting the relationship between the variables across the target groups. Pallant (2010) posits that descriptive statistics are used to (1) describe the characteristics of your sample in the Method section of your report, (2) check your variables for any violation of the assumptions underlying the statistical techniques that you will use to address your research questions; and address specific research questions. These analyses were carried out using statistical package for social science (SPSS) Version 20.

\section{Results and Discussion}

The analysis of the general information of the respondents shows that $58.14 \%$ of them work with contractors and $41.86 \%$ work with the consultant's firms. Also, the year of experience of the respondents was on an average of 11.87 years. Hence, the collected information can be relied upon, as the respondents have a considerable year of experience working in the construction industry. The analysis also, reveals that, in terms of respondents' profession, that the Quantity surveyors are more with $33.72 \%$, followed by the Engineers with $31.40 \%$.

On whether construction organizations have an employee dedicated to Research and Development (R \& D) on innovation, those who indicated 'Yes is $29.65 \%$ and ' $N o$ ' is $70.35 \%$. This implies that there are underlying factors that are limiting the full-scale uptake, deployment and expansion of innovative activities in the organizations. Therefore, more efforts are still required in areas of adoption of new techniques and innovative technologies.

\section{Limiting Factors of Innovation}

The result of the analysis of the views of the participants is presented in Table 1. From the table, and according to the contractors group, the top 5 factors limiting innovation in order of their magnitude are insufficient/inadequate support and commitment from management (MIS = 4.68), inadequate funding (limited budget) (MIS = 4.54), poor coordination and communication among project participants (MIS = 4.35 ), fragmented nature of the construction business (MIS $=4.33$ ) and poor innovation motivators in an organizations (MIS $=4.28$ ).

For the consultants, the top 5 factors limiting innovations in the construction industry are inadequate funding (limited budget) (MIS = 4.67), insufficient/inadequate support and commitment from management (MIS = 4.49), Lack of qualified and experienced staff to initiate and manage innovation (MIS = 4.31), unwillingness of clients to pay for innovative ideas (MIS $=4.29$ ) and fragmented nature of the construction business (MIS $=4.29$ ).

Overall, the factors limiting process and product innovations in the Nigerian construction industry are inadequate funding (limited budget) (MIS=4.61), insufficient/inadequate support and commitment from management (MIS=4.59), fragmented nature of the construction business (MIS=4.32), poor coordination and communication among project participants (MIS=4.21), lack of qualified and experienced staff to initiate and manage innovation (MIS=4.16), and unwillingness of clients to pay for innovative ideas (MIS=4.16). 
However, all the identified factors have a limiting effect on the uptake and sustenance of innovations in the industry as they have their mean item scores to be above 3.50, and with an overall average of 3.90 (78.01\%). This implies that regardless of the relative rating of these factors by the participants, there is an agreement that they hinder the uptake and sustenance of innovative solutions by construction-based organizations.

Table 1 - Limiting factors to innovation in construction-based organizations

\begin{tabular}{|c|c|c|c|c|c|c|c|}
\hline \multirow[t]{2}{*}{ S/No } & \multirow[t]{2}{*}{ Factors } & \multicolumn{2}{|c|}{ Contractors } & \multicolumn{2}{|c|}{ Consultants } & \multicolumn{2}{|c|}{ Overall } \\
\hline & & MIS & Rank. & MIS & Rank. & MIS & Rank. \\
\hline 1 & $\begin{array}{l}\text { Lack of qualified and experienced staff to } \\
\text { initiate and manage innovation }\end{array}$ & 4.00 & $9^{\text {th }}$ & 4.31 & $3^{\text {rd }}$ & 4.16 & $5^{\text {th }}$ \\
\hline 2 & $\begin{array}{l}\text { Excessive subcontracting of construction } \\
\text { works }\end{array}$ & 3.68 & $13^{\text {th }}$ & 3.58 & $15^{\text {th }}$ & 3.64 & $16^{\text {th }}$ \\
\hline 3 & Inadequate funding (limited budget) & 4.54 & $2^{\text {nd }}$ & 4.67 & $1^{\text {st }}$ & 4.61 & $1^{\text {st }}$ \\
\hline 4 & $\begin{array}{l}\text { Poor innovation motivators in an } \\
\text { organizations }\end{array}$ & 4.28 & $5^{\text {th }}$ & 3.96 & $9^{\text {th }}$ & 4.12 & $8^{\text {th }}$ \\
\hline 5 & $\begin{array}{l}\text { The unwillingness of clients to pay for } \\
\text { innovative ideas }\end{array}$ & 4.02 & $7^{\text {th }}$ & 4.29 & $4^{\text {th }}$ & 4.16 & $5^{\text {th }}$ \\
\hline 6 & $\begin{array}{l}\text { Lack of requisite skills to manage risks of } \\
\text { innovation }\end{array}$ & 3.09 & $18^{\text {th }}$ & 3.21 & $19^{\text {th }}$ & 3.15 & $19^{\text {th }}$ \\
\hline 7 & $\begin{array}{l}\text { Poor leadership for innovation by project } \\
\text { managers }\end{array}$ & 3.62 & $15^{\text {th }}$ & 4.07 & $7^{\text {th }}$ & 3.85 & $10^{\text {th }}$ \\
\hline 8 & $\begin{array}{l}\text { Fragmented nature of the construction } \\
\text { business }\end{array}$ & 4.33 & $4^{\text {th }}$ & 4.29 & $4^{\text {th }}$ & 4.32 & $3^{\text {rd }}$ \\
\hline 9 & $\begin{array}{l}\text { Insufficient/inadequate support and } \\
\text { commitment from management }\end{array}$ & 4.68 & $1^{\text {st }}$ & 4.49 & $2^{\text {nd }}$ & 4.59 & $2^{\text {nd }}$ \\
\hline 10 & Temporary nature of construction projects & 4.09 & $6^{\text {th }}$ & 4.18 & $6 \mathrm{~h}$ & 4.14 & $7^{\text {th }}$ \\
\hline 11 & $\begin{array}{l}\text { Lack/unwillingness of organizational drive } \\
\text { to innovative changes }\end{array}$ & 3.67 & $14^{\text {th }}$ & 3.68 & $13^{\text {th }}$ & 3.68 & $13^{\text {th }}$ \\
\hline 12 & $\begin{array}{l}\text { The premium placed by procurement } \\
\text { systems on speed, urgency and/or price for } \\
\text { delivering projects }\end{array}$ & 3.73 & $12^{\text {th }}$ & 3.39 & $17^{\text {th }}$ & 3.56 & $17^{\text {th }}$ \\
\hline 13 & $\begin{array}{l}\text { Lack of clients/owners support for } \\
\text { innovation }\end{array}$ & 3.54 & $17^{\text {th }}$ & 3.88 & $11^{\text {th }}$ & 3.71 & $11^{\text {th }}$ \\
\hline 14 & $\begin{array}{l}\text { clients' being Inexperience and uninformed } \\
\text { about innovations }\end{array}$ & 3.83 & $10^{\text {th }}$ & 3.57 & $16^{\text {th }}$ & 3.70 & $12 \mathrm{~h}$ \\
\hline 15 & Short-term budgets and planning horizons & 3.55 & $16^{\text {th }}$ & 3.74 & $12^{\text {th }}$ & 3.65 & $15^{\text {th }}$ \\
\hline 16 & $\begin{array}{l}\text { ineffective management of knowledge } \\
\text { transfer }\end{array}$ & 3.04 & $19^{\text {th }}$ & 3.39 & $17^{\text {th }}$ & 3.22 & $18^{\text {th }}$ \\
\hline 17 & $\begin{array}{l}\text { Poor coordination and communication } \\
\text { among project participants }\end{array}$ & 4.35 & $3^{\text {rd }}$ & 4.06 & $8^{\text {th }}$ & 4.21 & $4^{\text {th }}$ \\
\hline 18 & Lack of Technologies & 4.01 & $8^{\text {th }}$ & 3.90 & $10^{\text {th }}$ & 3.96 & $9^{\text {th }}$ \\
\hline 19 & Government policies & 3.75 & $11^{\text {th }}$ & 3.60 & $14^{\text {th }}$ & 3.68 & $13^{\text {th }}$ \\
\hline & Average & & & & & $\begin{array}{c}3.90 \\
(78.01 \%)\end{array}$ & \\
\hline
\end{tabular}

\section{Determining the Relationship between the Target Group}

From the descriptive statistics result in Table 2, the mean for the views of the two different respondents group is almost the same. The mean for the contractor's perception of the identified factors limiting 
innovation is 3.88, while that of the consultant group is 3.91. Furthermore, In addition, standard deviations of the two groups are very little. That is contractors $(\mathrm{SD}=0.471)$ and consultants $(\mathrm{SD}=0.505)$. The result of the descriptive statistics gives an early indication that there is no statistical difference in the views of the two participant group. Therefore, the participant's view of the variables that limit innovation in construction work is the same.

Table 2 - Group Statistics of Respondents Group

\begin{tabular}{lccccc}
\hline & Respondents Group & N & Mean & Std. Deviation & Std. Error Mean \\
\hline Variables & Contractors & 100 & 3.88 & 0.471 & 0.047 \\
& Consultants & 72 & 3.91 & 0.505 & 0.059 \\
\hline
\end{tabular}

In order to give an in-depth explanation of the mean difference between the groups, the result of the inferential statistics in Table 3 was used. A look at the 'Levene's Test for Equality of Variances', shows that pvalue is 0.450 which is greater than 0.05 significant level. This, therefore, implies that the variance of the two groups is the same. Having recorded a p-value of greater than 0.05 , the relationship between the mean of the two groups will be deduced from the 'Equal variance assumed' column of the inferential statistics table. Furthermore, Sig. (2-tailed) value of 0.711 is greater than 0.05 significant level, showing that there is no significant statistical difference between the two groups. Similarly, the sign of the t-value is the same with the sign of the difference between the mean of the contractors and the mean of the consultants (i.e. $3.88-3.91=$ -ve). Another confirmation of the result of the Sig. (2-tailed) is that the df must be closer to the total number of participants in the study. Thus, a critical look at the table shows that $\mathrm{df}=170$, which is very close to the sample size of 172 . Therefore, no statistically significant difference exist between the contractors and consultants, hence, the hypothesis is accepted.

Table 3 - Independent Samples Test

\begin{tabular}{llcc}
\hline & & \multicolumn{2}{c}{ Variables } \\
\hline & & $\begin{array}{c}\text { Equal variances } \\
\text { assumed }\end{array}$ & $\begin{array}{c}\text { Equal variances not } \\
\text { assumed }\end{array}$ \\
Levene's Test for Equality of & F & 0.574 & \\
Variances & Sig. & 0.450 & -0.367 \\
t-test for Equality of Means & t & -0.371 & 146.54 \\
& df & 170 & 0.714 \\
& Sig. (2-tailed) & 0.711 & -0.0279 \\
& Mean Difference & -0.0279 & 0.0760 \\
& Std. Error Difference & 0.0751 & 0.1204 \\
& 95\% CI: Lower & -0.1761 & 0.1222 \\
\hline
\end{tabular}

Thus, drawing from Table 2 and Table 3, it was concluded that there is no statistically significant difference between the contractors (MIS=3.88, $\mathrm{SD}=0.471)$ and consultants $(\mathrm{MIS}=3.91, \mathrm{SD}=0.505)$ regarding the factors that limit innovation in the construction industry of Nigeria (t170 $=-0.371, \mathrm{p}=0.711)$. Innovation in both contracting and consulting organizations are limited by the same factors.

\section{Discussion}

The study reported an agreement among the participants regarding the factors that hinder the uptake and sustenance of innovative solutions by construction-based organizations. It was found that poor funding availability, poor support and commitment from management, fragmented nature of the construction business, poor coordination and communication among project participants, lack of qualified and experienced staff to initiate and manage innovation and unwillingness of clients to pay for innovative ideas are the critical factors limiting innovations by construction base organizations. These findings are consistent with the report 
of (Blayse \& Manley, 2004; Dewick \& Miozzo, 2004; Wei \& Lam, 2014; Yankah \& Dadzie, 2015). Wei and Lam (2014) reported that narrow budget, organizational inefficiency, information management, availability of qualified staff, are resource based factors hindering innovations. These factors were considered as both internal and external dynamics forces that influence organizational innovations (Blayse \& Manley, 2004). The biggest issues faced by construction projects has always been budgetary provision. The fear of cost overruns and the need for radical innovative solutions when there are technical challenges trigger innovation. Limited finance is, therefore, a barrier to innovation.

Yankah and Dadzie (2015) reported that the innovative activities of consultants like quantity surveyors are limited by the availability of financial resources, economic conditions, fragmented nature of construction business, inappropriate legislation, believe that the industry is doing well without innovation, and lack of qualified staff.

The presence of some project managers who are non-construction based university graduates in the construction business is a barrier to innovation in the industry. Some of these managers are not experienced and are lacking grossly in leadership issues, as such key decisions on innovation are most times ignored. Thus, communicating new technological ideas and techniques become a difficult task where top managers are not giving the needed support to innovative ideas and solutions; this was pointed out by (Wei \& Lam, 2014). Wei and Lam (2014) reported that a lot of complaints on the excessive use of specialized innovative subcontractors which culminate to contractors to have to lose opportunities for innovation. Also, overreliance on companies procedures during the discharge of innovation activities were tough and increases the risk of failure during formal application. Contractors are aversive, and have ready risk response plan should there be a failure of innovation. This attitude does not favor innovation as reported by (Wei \& Lam, 2014). Therefore, management support is key to the success of innovation. A weak motivational and strong penalizing culture of organizations is a problem to innovations. Without motivation, especially reward system, employees are reluctant to venture into new ideas. Thus, the commitment of organizations to motivating innovative ideas will favor innovation by employees

Highly qualified professional staff are key to the initiation and management of innovation. This influences the level of innovation a team can possess (Blayse \& Manley, 2004; Gann, 2001). Therefore, the innovativeness and creativity of prospective staffs should be paramount at the time of recruitment.

The nature of construction works has been highlighted as a barrier to innovation. Construction projects are usually time bound with a short-term relationship amongst the team. The short-term nature of the work hinders the continuous sharing of established knowledge and experiences (Dubois \& Gadde, 2000). Innovation cannot survive within the short-term periods of construction projects (Mulgan \& Albury, 2003). Also, the fragmented and project-based nature of the construction industry impedes improvement in performance (Egan, 1998; Winch, 1998).

Clients play a critical role in innovations, as their conservative disposition and willingness can mar or make sustenance of innovations practices (Blayse \& Manley, 2004; Dewick \& Miozzo, 2004). Wei and Lam (2014) reported that clients are conservative and are only willing to only adopt familiar solutions. Thus, innovative customers are uncommon, except for corporate organizations who are experienced and have a pool of good in-house support team. Since the services and products of the construction industry are triggered by the demands of clients, the position of clients to innovative solutions remained very vital. Also, according to Morledge (2000), clients' reluctance to embrace new techniques and ideas, and lack of access to new techniques and/or innovative ideas are factors limiting innovation.

Finance is the oil that lubricates every unit of an organization. It is at the center of the operations of an organizational system. Thus, it is regarded as the backbone to the survival and advancement of an 
organization. The decision of management to encourage or embark on innovation must be backed up by funding provision, without which innovation dies. Management supports begins with a decision to innovate, provision of finance and the enabling atmosphere for experienced and qualified staffs/employees to develop new ideas/ways of doing things and managing innovation. Maintaining a strong pool of experienced staff or professionals to boost the company image is key to remaining above the competition. This strategy is critical to the survival and existence of any construction firm. Thus, it's an innovative marketing strategy employed by corporate organizations for attracting, keeping and maintaining their clients. The company technical knowledge and employees' competence is important to innovation. The ever-changing pace in Information and communication technology and innovation, calls for knowledge development among the members of the company as the key to their competitiveness and capability to remain in the front line. Poor communication amongst project participants has been identified as the critical factor responsible for so many issues in construction. Poor communication between parties may also lead to conflicts and claims, misinterpretation of requirements; these have a negative impact on workflow. Poor coordination and exchanges of information amongst the client, design consultants, and contractors are the most factors responsible for poor dissemination of innovative ideas, the dead of conceived ideas among others. Therefore, an innovating company is most likely going to fail to achieve it aim, when there is lack of the needed management support, poor communication and financial provision and without the right quality or pool of experienced staff

\section{Conclusion and Recommendations}

The study evaluated the factors limiting the full-scale adoption of process and product innovation by construction organizations (contractors and consultants) in Nigeria with a view to suggesting probable ways of eliminating them. The study found that innovation in both the contractors and consultants organizations are majorly limited by the same factors, such as funding and poor support of top management. Also, poor funding, weak support and commitment from management, fragmented nature of the construction business, poor coordination and communication among project participants, lack of qualified and experienced staff to initiate and manage innovation and unwillingness of clients to pay for innovative ideas are the critical factors limiting the initiation, uptake and sustenance of innovations by construction base organizations in Nigeria.

While recognizing the role of finance and management support in every construction activity, corporate organizations should endeavor to make provisions to take up innovative ideas, as at the long run the benefits will completely outweigh the cost. Shareholders of any organization would usually appreciate its company to be on top of its competitors. Thus, management support is critical to achieving this and ensuring continues revenue stream. Similarly, effective communication should be encouraged in organizations that desire to remain on top of its industry. Staff training, re-training, and education is also important to match up the everchanging world of information technology and technological advancement. It is normal that when issues that hinder performance and limit business growth are fixed, clients would be willing to patronize and pay for their services, so long as value for monies committed will be achieved. Clients satisfactory is key to getting clients to pay for innovative solutions, and this lies in the ability of the company management to convince its customers on performance.

Innovation is key to remaining above competitors, and as such, it should be captured in the policy statement of organizations and a conducive atmosphere should be provided, that will give room for tolerance and commitment from its employees. The continues information on the benefits and importance of innovation cannot be overemphasized, therefore, it is recommended that similar studies that would reveal more barriers to innovation should be embarked upon, either within the same region or other areas and states of the country. Furthermore, a similar study should be embarked upon using top management as the study respondents. Also, a study aim at finding an effective solution to overcoming barriers to innovation should be embarked upon. 


\section{References}

Aghimien, D. O., Oke, A. E., \& Aigbavboa, C. O. (2018). Barriers to the adoption of value management in developing countries. Engineering, Construction and Architectural Management, 25(7), 818-834. doi: 10.1108/ECAM-04-2017-0070

Akintoye, A. (2000). Analysis of factors influencing project cost estimating practice. Construction Management and Economics, 18(1), 77-89. doi: 10.1080/014461900370979

Alaghbandrad, A., Asnaashari, E., \& Preece, C. (2012). Problems and barriers of ICT utilization on Iranian construction sites: Case study on the successful use of ICT in remote construction sites. Journal of Information Technology in Construction (ITcon), 17(6), 93-102.

Alinaitwe, H., Widen, K., Mwakali, J. A., \& Hansson, B. (2006). Building Firm Innovation Enablers and Barriers Affecting Productivity Proceedings from the International Conference on Advances in Engineering and Technology (pp. 268-276): Elsevier.

Aouad, G., Ozorhon, B., \& Abbott, C. (2010). Facilitating innovation in construction: Directions and implications for research and policy. Construction Innovation, 10(4), 374-394. doi: $10.1108 / 14714171011083551$

Barrett, P., \& Sexton, M. (2006). Innovation in Small, Project-Based Construction Firms. British Journal of Management, 17(4), 331-346. doi: 10.1111/j.1467-8551.2005.00461.x

Benmansour, C., \& Hogg, K. (2002). An Investigation into The Barriers io Innovation and their Relevance within the Construction Sector. 10.

Blaxter, L., Hughes, C., \& Tight, M. (2001). How to research (2nd ed.). Buckingham ; Philadelphia: Open University Press.

Blayse, A. M., \& Manley, K. (2004). Key influences on construction innovation. Construction Innovation, 4(3), 143-154. doi: 10.1108/14714170410815060

Brandon, P. S., Kocatürk, T., \& Foundation, R. (2008). Virtual futures for design, construction \& procurement. Oxford ; Malden, MA: Blackwell Pub.

Bresnen, M., Goussevskaia, A., \& Swan, J. (2005). Implementing change in construction project organizations: exploring the interplay between structure and agency. Building Research \& Information, 33(6), 547-560. doi: 10.1080/09613210500288837

Davidson, C. (2013). Innovation in construction - before the curtain goes up. Construction Innovation, 13(4), 344-351. doi: 10.1108/CI-02-2013-0007

Demir, C., \& Kocabaş, İ. (2010). Project Management Maturity Model (PMMM) in educational organizations. Procedia - Social and Behavioral Sciences, 9, 1641-1645. doi: 10.1016/j.sbspro.2010.12.379

Dewick, P., \& Miozzo, M. (2002). Sustainable technologies and the innovation-regulation paradox. Futures, 34(9-10), 823-840. doi: 10.1016/S0016-3287(02)00029-0 
Dewick, P., \& Miozzo, M. (2004). Networks and innovation: sustainable technologies in Scottish social housing. $R$ and D Management, 34(3), 323-333. doi: 10.1111/j.1467-9310.2004.00342.x

Dodgson, M., Gann, D., \& Salter, A. (2005). Think, Play, Do: Innovation, Technology, and Organization. Oxford, New York: Oxford University Press.

Dougherty, D. (2006). Organizing for Innovation in the 21st Century The SAGE Handbook of Organization Studies (2 ed., pp. 598-617). London: SAGE Publications Ltd.

Dubois, A., \& Gadde, L.-E. (2000). Supply strategy and network effects — purchasing behaviour in the construction industry. European Journal of Purchasing \& Supply Management, 6(3-4), 207-215. doi: 10.1016/S0969-7012(00)00016-2

Dulaimi, M. F., Nepal, M. P., \& Park, M. (2005). A hierarchical structural model of assessing innovation and project performance. Construction Management and Economics, 23(6), 565-577. doi: 10.1080/01446190500126684

Egan, S. J. (1998). Rethinking Construction - The report of the Construction Task Force. Retrieved from http://constructingexcellence.org.uk/resources/rethinking-construction-the-egan-report/

Egbu, C. O., Henry, J., Kaye, G. R., Quintas, P., Schumacher, T. R., \& Young, B. A. (1998). Managing organizational innovations in construction.

Eriksson, P. E. (2013). Exploration and exploitation in project-based organizations: Development and diffusion of knowledge at different organizational levels in construction companies. International Journal of Project Management, 31(3), 333-341. doi: 10.1016/j.ijproman.2012.07.005

Fairclough, J. (2002). Rethinking Construction Innovation And Research - A Review Of The Government's R\&D Policies And Practices.

Gann, D. (2001). Putting academic ideas into practice: technological progress and the absorptive capacity of construction organizations. Construction Management and Economics, 19(3), 321-330. doi: $10.1080 / 01446190010020480$

Goh, A. L. S. (2005). Promoting innovation in aid of industrial development: the Singaporean experience. International Journal of Public Sector Management, 18(3), 216-240. doi: 10.1108/09513550510591524

Hunt, R. J., \& Gonzalez, V. A. (2018). Innovation in the New Zealand Construction Industry - Diffusion of the Last Planner System. Paper presented at the 26th Annual Conference of the International Group for Lean Construction.

Kelley, B. (2010). Stoking your innovation bonfire: A roadmap to a sustainable culture of ingenuity and purpose: John Wiley \& Sons.

Kuczmarski, T. D. (1996). What is innovation? The art of welcoming risk. Journal of Consumer Marketing, 13(5), 7-11. doi: 10.1108/07363769610130846 
Kumaraswamy, M., \& Dulaimi, M. (2001). Empowering innovative improvements through creative construction procurement. Engineering Construction and Architectural Management, 8(5-6), 325-334. doi: 10.1046/j.1365-232X.2001.00215.x

Lim, J. N., Schultmann, F., \& Ofori, G. (2010). Tailoring Competitive Advantages Derived from Innovation to the Needs of Construction Firms. Journal of Construction Engineering and Management, 136(5), 568-580. doi: 10.1061/(ASCE)CO.1943-7862.0000151

Manley, K. (2008). Against the odds: Small firms in Australia successfully introducing new technology on construction projects. Research Policy, 37(10), 1751-1764. doi: 10.1016/j.respol.2008.07.013

Mazzola, B. G., Oliveira Junior, M. D. M., Esteves, K., \& Barreto, L. F. B. P. d. M. (2018). Innovation management in micro, small and medium-sized companies: a study in a Brazilian electro-electronic cluster. Independent Journal of Management \& Production, 9(4), 1354. doi: 10.14807/ijmp.v9i4.833

Moohammad, A., Nor'Aini, Y., \& Kamal, E. (2014). Empirical assessment of Nigerian construction industry consultancy services innovation practices. International Journal of Managerial Studies and Research, 2(9), 175-186.

Morledge, R. (2000). Marketing-a solution to construction market failure. International Journal of Construction Marketing, 1(1).

Moser, C., \& Kalton, G. (2001). Survey methods in social investigation. Aldershot: Ashgate.

Mulgan, G., \& Albury, D. (2003). Innovation in the public sector. Strategy Unit, Cabinet Office, 1, 40.

OECD. (1992). Oslo Manual: Proposed Guidelines for Collecting and Interpreting Technological Innovation Data, 2nd Edition - OECD. from https://www.oecd.org/sti/inno/oslomanualproposedguidelinesforcollectingandinterpretingtechnolog icalinnovationdata2ndedition.htm

Pallant, J. (2010). SPSS survival manual: A step by step guide to data analysis using SPSS (Vol. 2011).

Peansupap, V., \& Peansupap, V. (2004). An exploratory approach to the diffusion of ICT in a project environment.

Pöyhönen, P., Kajander, J. K., \& Sivunen, M. (2016). Innovation Management System for Construction Companies. 7.

Preece, C. N., Haron, R. C., \& Abdullah, H. (2008). The challenges and opportunities in marketing the QS practice in Malaysia. 14.

Quinn, J. B. (1985). Managing Innovation: Controlled Chaos. Harvard Business Review.

Reichstein, T., Salter, A. J., \& Gann, D. M. (2005). Last among equals: a comparison of innovation in construction, services and manufacturing in the UK. Construction Management and Economics, 23(6), 631644. doi: 10.1080/01446190500126940 
Sargent, K., Hyland, P., \& Sawang, S. (2012). Factors influencing the adoption of information technology in a construction business. Construction Economics and Building, 12(2), 86. doi: 10.5130/AJCEB.v12i2.2448

Seaden, G., Guolla, M., Doutriaux, J., \& Nash, J. (2003). Strategic decisions and innovation in construction firms. Construction Management and Economics, 21(6), 603-612. doi: 10.1080/0144619032000134138

Shaw, N. (2010). Improving innovation management in construction. (PhD Dissertation), (C Nicholas Shaw.

Sivunen, M., Pulkka, L., Heinonen, J., Kajander, J. K., \& Junnila, S. (2013). Service-dominant innovation in the built environment. Construction Innovation, 13(2), 146-164. doi: 10.1108/14714171311322138

Slaughter, E. S. (1998). Models of Construction Innovation. Journal of Construction Engineering and Management, 124(3), 226-231. doi: 10.1061/(ASCE)0733-9364(1998)124:3(226)

Slaughter, E. S. (2000). Implementation of construction innovations. Building Research \& Information, 28(1), 217. doi: 10.1080/096132100369055

Storey, J. (2000). The management of innovation problem. International Journal of Innovation Management, 04(03), 347-369. doi: 10.1142/S1363919600000196

Tan, W. (2008). Practical Research Methods Third Edition (Third Edition ed.). Singapore: Pearson Education.

Usman, N. (2014). Key Factors that Affects Adoption of Technology in the Nigerian Construction Firms: A Theoretical Framework.

Wei, Y., \& Lam, P. T. I. (2014). Innovation Barriers at the Project Level: Study of a UK Construction Firm.

Winch, G. (1998). Zephyrs of creative destruction: understanding the management of innovation in construction. Building Research \& Information, 26(5), 268-279. doi: 10.1080/096132198369751

Winch, G. (2003). How innovative is construction? Comparing aggregated data on construction innovation and other sectors - a case of apples and pears. Construction Management and Economics, 21(6), 651-654. doi: 10.1080/0144619032000113708

Wong, C. H. (2007). ICT implementation and evolution: Case studies of intranets and extranets in UK construction enterprises. Construction Innovation, 7(3), 254-273. doi: 10.1108/14714170710754740

Yankah, J. E., \& Dadzie, D. K. (2015). Push and Pull factors of Innovation Performance in Quantity Surveying Firms. Journal of Economics and Sustainable Development, 6(20), 188-196-196. 